\title{
Mass and Moisture Distribution in Aboveground Components of Standing Corn Plants
}

\author{
C. Igathinathane, A. R. Womac, S. Sokhansanj, L. O. Pordesimo
}

\begin{abstract}
Corn stover mass and moisture properties were identified to aid decisions regarding collection of standing corn stover dry matter with least moisture, and to aid development of moisture prediction tools for applications including harvest, transport, size reduction, and storage. Vertical distributions of mass and moisture in standing stalks and aboveground components such as leaf, husk, and ear in standing corn plants were evaluated over time. Stalks were cut into 254 mm long sections to facilitate analysis, and to correspond with billet length collected for cane-type crops. Stalks had the greatest wet mass (72.6\%) followed by leaf (20.7\%) and husk (6.8\%) during the normal harvest period. Moisture profile in aboveground plant components exhibited two separate, sequential linear relationships when plotted with time. The first zone was rapid moisture reduction prior to the normal harvest period. The second zone, corresponding with but not the result of grain harvest, had slow, gradual moisture reduction and stabilization. Geometrical analyses of stalk cross-sectional area, volume, and lateral surface area to volume ratio documented physical properties for future moisture prediction tools. Considering stalks only, the bottom 1 to 4 stalk sections had 60.6\% of total dry matter, although that was the last portion of the stalk to dry, thereby increasing the liability of added moisture on transportation and storage. An apparent drying front moved downward through the plant over time and may be explained by reduced the lateral surface area to volume ratio from stalk top to stalk bottom. Dry matter and moisture content of stalks were not significantly influenced by the observed soil and environmental parameters, including rainfall. It was hypothesized that standing stalks readily shed rainfall and allowed less opportunity for moisture penetration. Mass and moisture content of discrete stalk sections were normalized using plant height to facilitate multiple regression equations applicable to other crop heights. Results pertain to assessment of mass and moisture status of standing stalks in the field before and after grain harvest, identity of moisture factors related to the supply of uniform-quality feedstock, and discovery of relevant biomass properties needed for design and management of efficient biomass processes and equipment.
\end{abstract}

Keywords. Bioenergy, Biomass, Corn stover, Harvest, Size reduction, Storage, Transport.

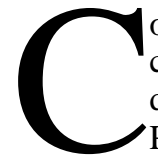

orn (Zea mays, L.) stover was strategically conceived as biomass for bioenergy and bio-based industrial products (Hettenhaus and Wooley, 2000). Potential stover applications include animal feed, fuel, particle board, building panel, pulp and paper, ethanol, cellulose derivatives, potting soil, and roadside mulching (Kadam and McMillian, 2003). An abundance of corn stover resulted from large annual plantings of $\sim 28$ million ha (USDA, 2005) producing 215 million t grain ( $15 \%$ moisture content, wet basis (w.b.)). Researchers used production area/ grain yield to estimate available corn stover. Sokhansanj et

Article was submitted for review in October 2004; approved for publication by the Food \& Process Engineering Institute Division of ASABE in January 2006. Presented at the 2004 ASAE Annual Meeting as Paper No. 041162.

The authors are Igathinathane Cannayen, ASABE Member Engineer, Post-Doctoral Research Associate, and Alvin R. Womac, ASABE Member Engineer, Professor, Department of Biosystems Engineering and Soil Science, The University of Tennessee, Knoxville, Tennessee; Shahab Sokhansanj, ASABE Member Engineer, Distinguished Research Scientist, Oak Ridge National Laboratory, Environmental Sciences Division, Oak Ridge, Tennessee; and Lester O. Pordesimo, ASABE Member Engineer, Agricultural Engineer, USDA-ARS Instrument and Sensing Lab, Beltsville, Maryland. Corresponding author: Alvin R. Womac, Department of Biosystems Engineering and Soil Science, The University of Tennessee, 2506 E. J Chapman Dr., Knoxville, TN 37996-4531; phone: 865-974-7104; fax: 865-974-4514; e-mail: awomac@utk.edu. al. (2002) estimated dry corn stover mass of 216 million $t$ from the 2001 U.S. corn grain yield. Other stover estimates were 64-91, 153, and 82 million dry t/y (Iowa State University, 1993; Glassner et al., 1999; Kadam and McMillian, 2003; respectively). Actual availability for bioconversion depended on estimates of minimum stover required for field maintenance for soil conservation, nutrients, and carbon.

Projected biorefinery need for stover was 172 million $\mathrm{t} / \mathrm{y}$ by 2010 and more than 508 million t/y by 2020 (Sokhansanj and Wright 2002). Meeting such industrial-scale needs on a year-round basis requires a uniform supply of predictable quality feedstock. Feedstock quality may impact bioconversion processes. Harvest, transport, size reduction, and storage operations also depend on feedstock characteristics. Sokhansanj (2005) developed the Integrated Biomass Supply Analysis and Logistics (IBSAL) model to predict feedstock supply system requirements due to various factors, including feedstock physicochemical characteristics. Feedstock mass and moisture strongly influence design requirements for feedstock supply systems, although available data for corn stover after grain harvest is limited. Cummins (1970), Leask and Daynard (1973), and Russell (1986) examined corn stover characteristics up to, but not after, physiological maturity of grain. Shinners et al. (2003) and Pordesimo et al. (2004) studied corn stover harvest, aboveground biomass distribution, components proportions, field drying after harvesting, and storage issues. 
Corn stover with high moisture content increases machine harvest difficulty, affects the selection of processing equipment, increases transportation cost, increases spoilage rate, and presents safety hazards when moldy (Edens et al., 2002; Jenkins and Sumner, 1986). Knowledge of corn stover mass and moisture would have utility to improve decisions on when to collect stover, what portions of stover to avoid, and what stover conditions to expect during collection. Empirical prediction relationships of stover mass and moisture may need to consider environmental factors, soil conditions, days after sowing (DAS), stalk geometrical properties, and ratio of lateral surface area to volume. Future deterministic models of moisture transfer from standing stover would benefit from additional empirical data. Pre- and post-harvest mass and moisture relationships provide baseline knowledge to manage corn stover efficient collection and use.

The objective of this research was to develop empirical mass and moisture distribution relationships of standing corn over a time period that spans pre- and post-harvest (without harvester effects). Results would aid decisions regarding collection of standing corn stover dry matter with least moisture, and aid development of moisture prediction tools for applications including harvest, transport, size reduction, and storage. Data applications include mathematical models for moisture status, and moisture-dependent measures of stalk cutting strength, thermodynamic properties, and noninvasive chemical composition analysis using near-infrared and nuclear magnetic resonance spectroscopy.

\section{Materials ANd Methods}

\section{Experimental Plot and Sample Collection}

Ten rows of corn plants of a field plot $(201 \times 48 \mathrm{~m})$ at The University of Tennessee Knoxville Experiment Station were selected for the study. The field had a well-drained alluvial soil (Sequatchie loam) on the first terrace of Fort Loudon Lake (Tennessee River). Corn variety Dekalb 743 was planted on 20 May 2003 after conventional tilling, and this date was considered as 0 DAS. Crop rows were spaced at $0.76 \mathrm{~m}$, and in-row plant spacing was approximately 0.2 to $0.25 \mathrm{~m}$. To avoid plot edge effects, plots had a minimum of seven border rows. Corn plants were over $3.5 \mathrm{~m}$ high when the experiment was started, and they generally had two corn ears. The main corn ear was always found above a smaller rudimentary ear (Aldrich and Leng, 1966), which is characteristic of single-ear corn varieties like Dekalb 743.

The experimental plot was divided into three blocks (replications) along the length, and two corn plants (subsamples) from each block were obtained each sample day. Plants were cut just above the node having brace roots. Samples were collected in the mid-morning hours except weekends. Sample period ranged from grain milky stage (11 August; 83 DAS) to well past harvesting date (24 October; 157 DAS). The normal harvest period was about 120 to 125 DAS, when the grain had around $25 \%$ moisture. No grain was harvested in plots to avoid mechanical disturbance of plants. Soil samples, one from each block, were collected each sample day at a depth of approximately $0.2 \mathrm{~m}$ and were held in airtight Whirl-Pak bags (Nasco, Fort Atkinson, Wisc.). One soil temperature measurement at an approximate depth of $0.14 \mathrm{~m}$ from each block was recorded using a dial-type soil thermometer. Collected plant and soil samples were transported to the laboratory within $30 \mathrm{~min}$ for analysis.

\section{Environmental Parameter Collection and EVAPOTRANSPIRATION ESTIMATION}

Weather data stored in $30 \mathrm{~min}$ intervals from an automatic weather station (model CM10, Campbell Scientific Inc., Logan, Utah) were downloaded and the data were consolidated on a daily basis. Component instruments of the weather station were a pyranometer (model LI2005, $\pm 3 \%$ typical error), tipping bucket rain gauge (model TE525, $\pm 1 \%$ accuracy), temperature and relative humidity probes (model $\mathrm{HMP} 45 \mathrm{C}, \pm 0.4^{\circ} \mathrm{C}$ and $\pm 2-3 \%$ relative humidity accuracy), and wind measurement (model 03001-5, R.M. Young wind sentry set with anemometer $\pm 0.5 \% \mathrm{~m} / \mathrm{s}$ accuracy and wind direction vane $5^{\circ}$ to $10^{\circ}$ accuracy), and data logger (model $\mathrm{CR} 10(\mathrm{X}))$. Environmental parameters monitored included solar radiation $\left(\mathrm{MJ} /\left(\mathrm{m}^{2} \cdot \mathrm{s}\right)\right)$, rainfall $(\mathrm{mm})$, maximum and minimum temperatures $\left({ }^{\circ} \mathrm{C}\right)$, mean air temperature $\left({ }^{\circ} \mathrm{C}\right)$, air relative humidity $(\%)$, wind speed $(\mathrm{m} / \mathrm{s})$, and wind direction $\left({ }^{\circ} \mathrm{N}\right)$.

REF-T Reference Evapotranspiration Calculator software, Ver. 2.0, developed by Allen (2000), was used to calculate the reference evapotranspiration from the measured environmental parameters. The FAO-56 Penman-Monteith method of the software was used in this study. An extract of the observed environmental conditions and calculated evapotranspiration values is given in table 1.

\section{Sample Preparation and Mass and Moisture MEASUREMENTS}

Wet mass of collected corn plants was measured first, and the aboveground components were separated manually. Corn ears were separated into husk and cob with kernels. The cob component of corn ears was arbitrarily not included exclusively in the study, since cob collection may not be practical for biomass due to reduced mass. Leaves were cut from stalks with scissors. Tassels were left attached to the stalks. All separated plant components, namely stalk, leaf, husk, and dehusked ear, from each of the six daily plant samples, were weighed separately using a digital balance. Stalks were divided into $254 \mathrm{~mm}$ long sections, which were numbered serially up to 14 . The stalks were then cut into sections, and the section's wet masses were measured individually (Igathinathane et al., 2004). Section length corresponded with billet length collected for cane-type crops. Shorter chop length, such as produced by a forage harvester, was not feasible due

Table 1. Environmental conditions and reference evapotranspiration values for Knoxville during 11 August to 24 October 2003.

\begin{tabular}{|c|c|c|c|c|}
\hline Variable & Mean & $\mathrm{SD}^{[\mathrm{a}]}$ & Min. & Max. \\
\hline Days after sowing (day) & 122.32 & 21.64 & 83 & 157 \\
\hline Soil moisture (\% w.b.) & 11.49 & 2.80 & 2.35 & 19.18 \\
\hline Soil temperature $\left({ }^{\circ} \mathrm{C}\right)$ & 21.42 & 3.85 & 13.0 & 29.0 \\
\hline Solar radiation $\left(\mathrm{MJ} /\left(\mathrm{m}^{2} \cdot \mathrm{s}\right)\right)$ & 16.83 & 5.32 & 2.55 & 23.58 \\
\hline Rainfall (mm/day) & 1.10 & 5.47 & 0.0 & 37.08 \\
\hline Mean air temperature $\left({ }^{\circ} \mathrm{C}\right)$ & 19.08 & 5.30 & 9.25 & 28.73 \\
\hline Maximum air temperature $\left({ }^{\circ} \mathrm{C}\right)$ & 26.30 & 4.73 & 14.5 & 33.4 \\
\hline Minimum air temperature $\left({ }^{\circ} \mathrm{C}\right)$ & 14.20 & 5.87 & 2.1 & 23.2 \\
\hline Air relative humidity (\%) & 79.02 & 7.49 & 57.01 & 95.9 \\
\hline Wind direction $\left({ }^{\circ} \mathrm{N}\right)$ & 139.29 & 40.45 & 62.13 & 243.8 \\
\hline Wind speed $(\mathrm{m} / \mathrm{s})$ & 0.88 & 0.44 & 0.392 & 2.722 \\
\hline$E T_{\mathrm{o}} \mathrm{FAO} 6-\mathrm{PM}^{[\mathrm{b}]}(\mathrm{mm} /$ day $)$ & 2.80 & 1.00 & 0.67 & 4.33 \\
\hline
\end{tabular}

[a] $\mathrm{SD}=$ standard deviation.

[b] Reference evapotranspiration by FAO-Penman-Monteith method (Allen, 2000). 
to the high number of stalk pieces to track during the experiment. Lengths determined by inter-node lengths were considered, but those varying lengths were avoided.

ASAE Standard S358.2 (ASAE Standards, 2003) for moisture measurement of forages (air oven at $103^{\circ} \mathrm{C}$ for $24 \mathrm{~h}$ ) was followed. Moisture contents of leaf and husk were determined from representative samples drawn after combining materials from all six plants. Approximately $55 \mathrm{~mm}$ long pieces were cut from sampled leaves and husks. One sample of manually shelled corn kernels from ears of each of six plants and three samples of soil from each of three blocks were prepared. Stalk sections were directly used in moisture content determination. Whole-stalk moisture content was determined as mass average moisture content. Whole-stalk wet mass was reported as averages of the six-stalk samples. Stalk section data were determined by averaging moisture contents among corresponding numbered stalk sections from six plants. In this article, all moisture contents are expressed in percentage w.b., unless stated otherwise.

\section{Dimensional Measurement and Selected \\ Geometrical Properties Estimation}

Stalk geometrical properties such as cross-sectional area, volume, and ratio of lateral surface area to volume were determined. Cross-sectional shape of corn stalk was elliptical, and stalk sections were geometrically assumed as tapered elliptical cylinders (elliptical frustum) (fig. 1). A dial-type vernier caliper with a resolution of $0.254 \mathrm{~mm}$ measured dimensions. Orthogonal measurements of width (major axis) and thickness (minor axis) were made at the bottom, middle, and top of each cut wet stalk section before moisture estimation. Nodal regions of stalks were avoided in the measurements. Elliptical cross-sectional areas at three levels of stalk sections are given as:

$$
A_{1}=\frac{\pi}{4} w_{1} t_{1} ; A_{2}=\frac{\pi}{4} w_{2} t_{2} ; A_{3}=\frac{\pi}{4} w_{3} t_{3}
$$

where

$$
\begin{aligned}
A_{1}, A_{2}, A_{3}= & \text { cross-sectional areas at bottom, middle, and } \\
& \text { top sections, respectively }\left(\mathrm{mm}^{2}\right)
\end{aligned}
$$
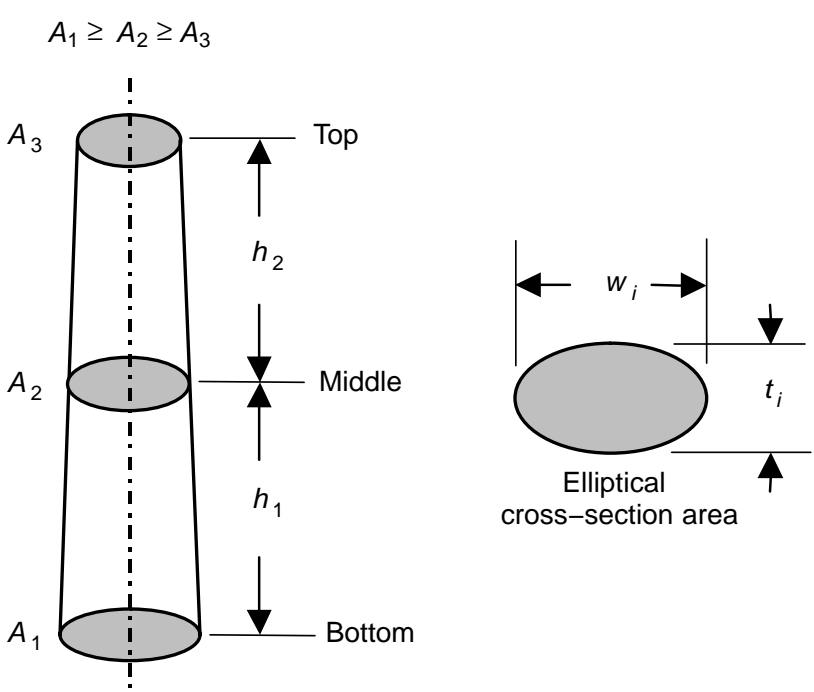

Figure 1. Schematic diagram of corn stalk section as elliptical frustum for geometrical properties analysis.

$$
\begin{aligned}
w_{1}, w_{2}, w_{3}= & \text { width (major axis) at bottom, middle and top } \\
& \text { sections, respectively (mm) } \\
t_{1}, t_{2}, t_{3}= & \text { thickness (minor axis) at bottom, middle and } \\
& \text { top sections, respectively (mm). }
\end{aligned}
$$

A mean equivalent diameter of a corresponding circular area equivalent to the elliptical cross-sectional area was obtained by combining the three areas (eq. 1). The mean lateral surface area $\left(A_{l s}\right)$ of a stalk section was obtained from the perimeter using the mean equivalent diameter and the section height. From the general formula for any frustum with known top and bottom areas separated by some distance (Weisstein, 2005), the total volume $\left(V_{t}\right)$ of a corn stalk section using the elliptical sectional areas was obtained. The ratio of lateral surface area to volume $\left(R_{a v}\right)$ of a stalk, which can perhaps be used as an indicator of moisture transfer potential, was derived as:

$$
\begin{aligned}
& R_{a v}=\frac{A_{l s}}{V_{t}}= \\
& \left\{\pi \sqrt{(1 / 3) \times\left(w_{1} t_{1}+w_{2} t_{2}+w_{3} t_{3}\right)} \times\left(h_{1}+h_{2}\right)\right\} \\
& \div\left\{(1 / 3) \times\left[h_{1}\left(A_{1}+A_{2}+\sqrt{A_{1} A_{2}}\right)\right.\right. \\
& \left.\left.+h_{2}\left(A_{2}+A_{3}+\sqrt{A_{2} A_{3}}\right)\right]\right\}
\end{aligned}
$$

where

$R_{a v} \quad=$ ratio of lateral surface area to volume of stalk section $(1 / \mathrm{mm})$

$A_{l s} \quad=$ mean lateral surface area of stalk section $\left(\mathrm{mm}^{2}\right)$

$V_{t} \quad=$ volume of stalk section $\left(\mathrm{mm}^{3}\right)$

$h_{1}, h_{2}=$ height of bottom and top portion of stalk section $(\mathrm{mm})$.

For geometrical measurements, only the first 12 sections were considered. Results were non-dimensionalized by normalizing along the stalk length to aid scale-up.

\section{Data Analysis}

The PROC REG procedure of SAS (2002) was used to develop linear and multiple regression equations. Simple independent variables like DAS and section numbers were prioritized as most useful for biomass management decisions. Statistical $t$-tests compared overall group means of closely related trends of corn stover components. PROC CORR of SAS (2002) was used to evaluate the correlation between various parameters.

\section{Results AND Discussion Mass and Moisture of Aboveground Plant COMPONENTS}

Mean wet mass values of stalk, ear, leaf, and husk during the experimental period are shown in figure 2. The mass reduction curves exhibit two distinct zones divided at 122 DAS, which coincides with the normal harvest period. The aboveground plant lost wet mass rapidly (from 1200 to $\sim 500 \mathrm{~g} /$ plant) linearly in the first zone, and gradually (from $\sim 500$ to $\sim 400 \mathrm{~g} / \mathrm{plant}$ ) in the second zone. Among components, stalk wet mass was initially the greatest, followed by ear, but ear wet mass was greatest after $\sim 112$ DAS. Leaf and husk lost wet mass rapidly in the first zone and stabilized about two weeks before the normal harvest period. Although 


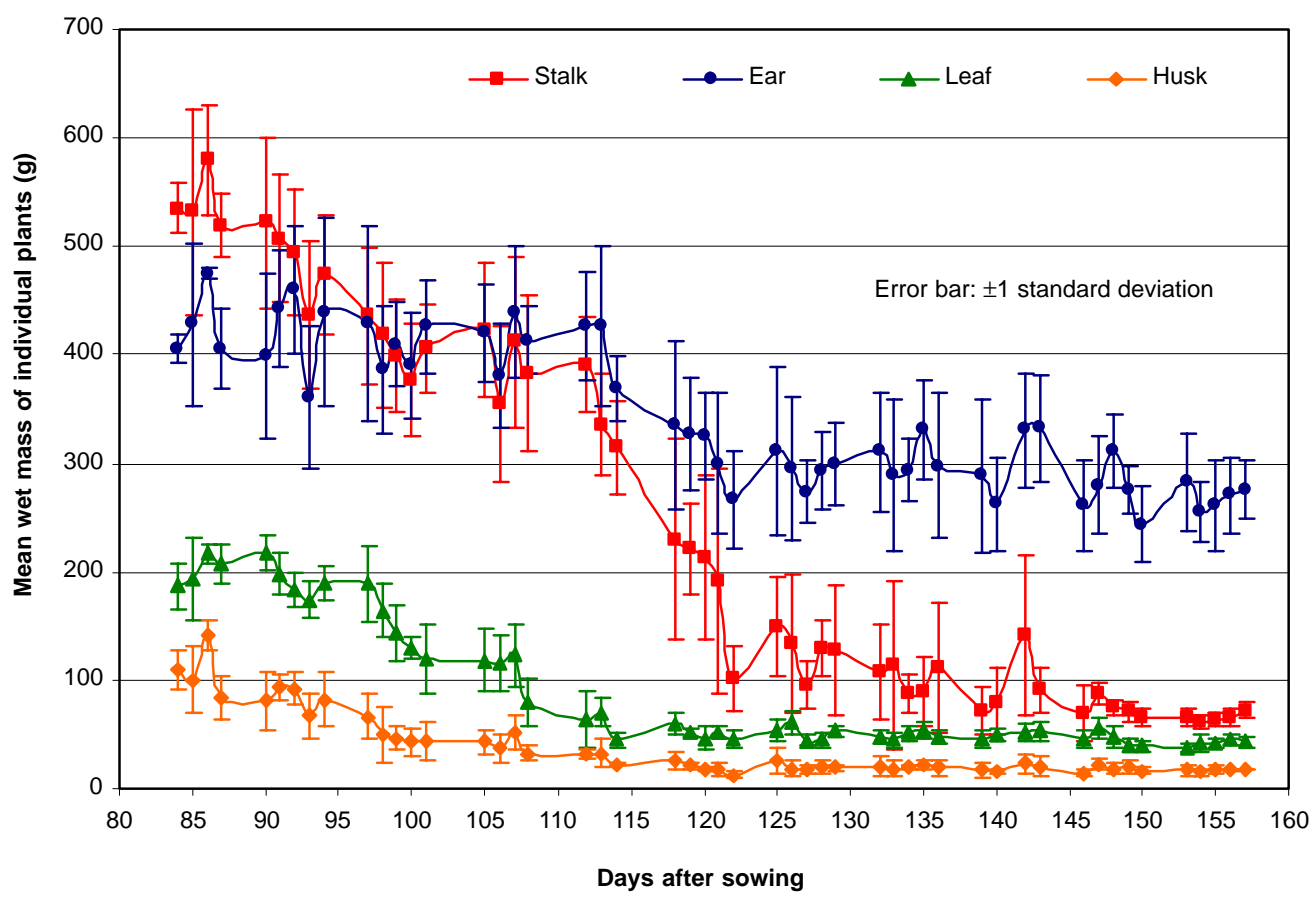

Figure 2. Wet mass of aboveground components of standing corn plants.

leaf and husk wet mass reductions had similar trends, the wet mass of leaf was $2.6 \pm 0.5$ times greater than that of husk, and their overall wet mass means were significantly different $(t=$ $-5.70, p<0.0001$ ). Dehusked ears (ear minus husk) exhibited relatively constant wet mass throughout the test period. Stalks dominated wet mass contribution (72.57\%) during the normal harvest period, followed by leaf $(20.67 \%)$ and husk $(6.76 \%)$, at mean grain moisture of $24.76 \%$.

Moisture content of stalk, grain, leaf, and husk exhibited greater graphical distinction than wet mass (fig. 3). Leaf, husk, and grain moisture decreased rapidly in the first zone $(\leq 122$ DAS $)$ and approached stabilized moisture thereafter (>122 DAS). Stalks had somewhat stable high moisture content $(>70 \%)$ before 120 DAS, and the moisture content decreased almost linearly to $10 \%$ from 120 to 157 DAS. Shinners et al. (2003) reported that the stalk moisture remained over $65 \%$ until grain harvest. For the study herein, leaf and husk overall mean moisture contents were not significantly different $(t=-0.96, p=0.3405)$. Stalk, leaf, husk, and grain achieved mean final moisture contents of $10.3 \%, 9.2 \%, 9.3 \%$, and $13.3 \%$, respectively. Four rainfall events $(89,103,118$, and 125 DAS) ranging from 10.7 to $37.1 \mathrm{~mm}$ did not have a substantial effect on mass and moisture of aboveground components. Measurement of corn moisture status did not attempt to identify sap flow or moisture movement through the roots. The exact date that

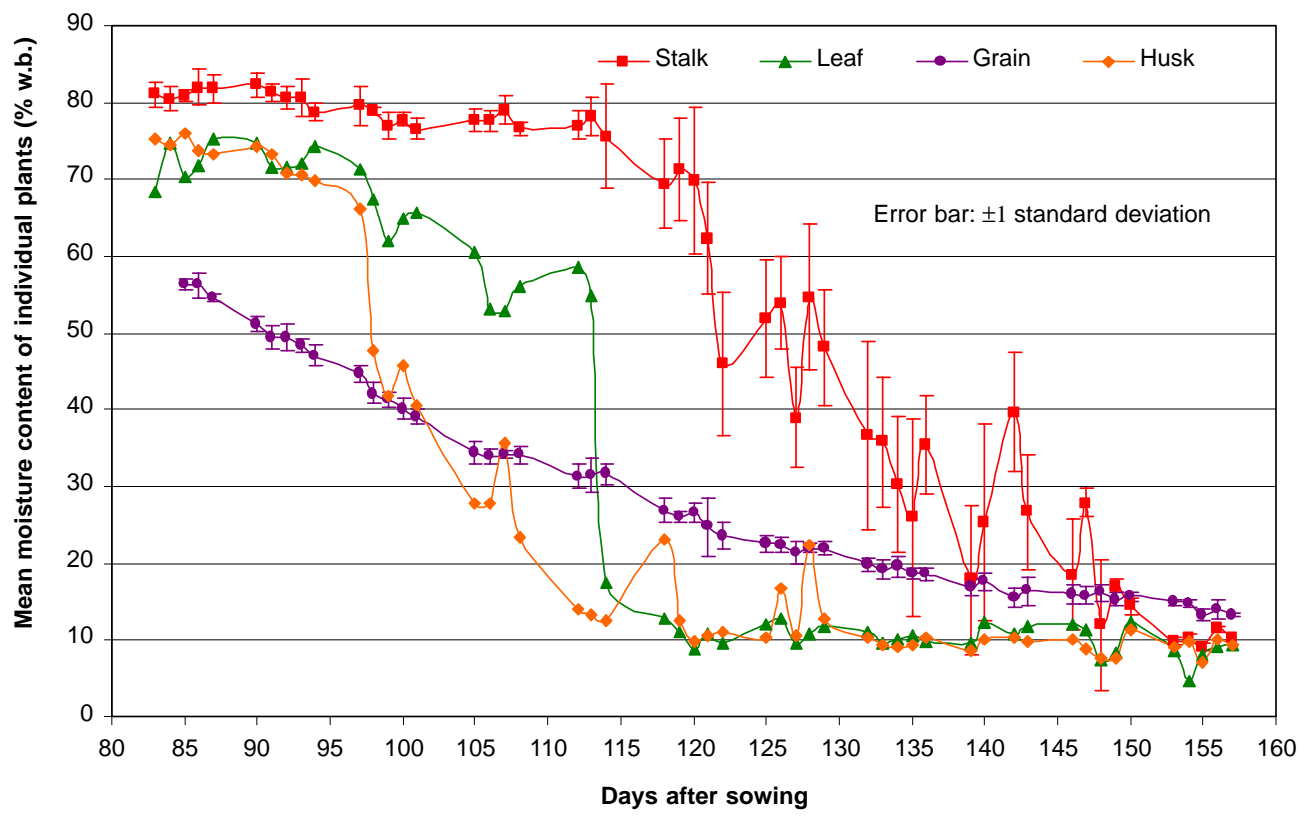

Figure 3. Moisture variation of aboveground components of standing corn plants. 
root moisture uptake stopped would be difficult to estimate based on information available in the literature. Most studies with actual sap flow measurements focused on the active growth season. For example, Jara et al. (1998) showed 50\% decreased sap flow in corn at mid-August. Future studies should consider this component measurement and the potential problems involved in distinguishing predominate sap/ moisture flow direction (hydration vs. dehydration).

Based on the dual, sequential linear responses of wet mass and moisture content with DAS (figs. 2 and 3), the total experimental period was divided into before-harvest (84 to $122 \mathrm{DAS}$ ) and after-harvest (125 to $157 \mathrm{DAS}$ ) periods. Linear regression relationships developed for wet mass with DAS are presented in table 2. Similar relationships developed for stalk dry matter, stover to ear ratio, and moisture content depict the rate of reduction over time. All equations for the before-harvest period were found to be highly significant ( $p<0.0001$ ), whereas some of the equations developed for the after-harvest period were not. Mass and moisture data stabilization and lack of clear variation after the normal harvest period (figs. 2 and 3) may have contributed to lack of fit in after-harvest models. Based on drying rates of the before-harvest period, stalk dried fastest, followed by leaf, whole ear, and husk. The stover to dehusked ear wet mass ratio decreased from 2.85 to 0.47 , with a mean of $1.20 \pm 0.74$, and the corresponding dry matter ratio decreased from 1.37 to 0.49 , with a mean of $0.68 \pm 0.23$, during the experimental period.

\section{Vertical Distribution of Mass and Moisture in a Single STALK}

Figure 4 shows the typical distribution of wet mass, dry matter, and moisture content along single stalk sections at two arbitrary days of 83 and 156 DAS. As dry matter of stalks was relatively similar for these two days, it was concluded that moisture differences primarily affected wet mass. It is interesting to note that the 4th stalk section's wet mass and dry matter are slightly higher than expected for a smooth upward trend. Considering all stalk samples, this anomaly had a frequency of $21 \%$ and $15 \%$ for wet mass and dry matter, respectively, and may have been related to a corn ear in the 5 th section. The main ear appeared at the 5th section with a frequency of $69 \%$, and at the 6th and 4th sections with a frequency of around $29 \%$ and $2 \%$, respectively. Increased wet mass and dry matter in the section below ears were observed with all plant samples throughout the experimental period. Tassels occurred above the 11th section and had comparatively very little wet mass.

\section{Variation of Geometrical Properties Along Stalk SECTIONS}

Two weeks of example data (98-101 DAS and 153-175 DAS) of mean diameters and volume ratios are presented in table 3. Diameter and volume ratios follow similar trends for a given week, with relatively less reduction among the 2 nd, 3rd, and 4th sections and large steady reduction among the other sections. Stalk shrinkage over time was probably due to moisture loss. Bottom stalk sections (1 to 4 ) had increased diameter ratios and volume ratios and less reduction. Diameter and volume ratios may be useful for determining cross-

Table 2. Wet mass and moisture content linear regression equations of aboveground corn plant components as a function of DAS.

\begin{tabular}{|c|c|c|c|c|c|c|}
\hline & Material & Harvest Period $^{[\mathrm{a}]}$ & Equation $^{[\mathrm{b}]}$ & $\mathrm{R}^{2}$ & $\mathrm{CV}(\%)$ & $\operatorname{Pr}>F$ \\
\hline \multirow{16}{*}{$\begin{array}{l}\text { Wet } \\
\text { mass } \\
(\mathrm{g})\end{array}$} & Whole plant & Before & $1248.630-17.448 \times(\mathrm{DAS}-84)$ & 0.890 & 8.24 & $<0.0001$ \\
\hline & & After & $491.197-3.691 \times(\mathrm{DAS}-125)$ & 0.554 & 8.16 & $<0.0001$ \\
\hline & Stalk & Before & $564.793-9.368 \times(\mathrm{DAS}-84)$ & 0.892 & 10.36 & $<0.0001$ \\
\hline & & After & $126.811-2.111 \times(\mathrm{DAS}-125)$ & 0.642 & 18.07 & $<0.0001$ \\
\hline & Leaf & Before & $219.806-4.875 \times(\mathrm{DAS}-84)$ & 0.929 & 12.94 & $<0.0001$ \\
\hline & & After & $52.975-0.330 \times(\mathrm{DAS}-125)$ & 0.340 & 10.28 & 0.0028 \\
\hline & Whole ear & Before & $448.448-2.872 \times(\mathrm{DAS}-84)$ & 0.478 & 9.46 & $<0.0001$ \\
\hline & & After & $306.019-1.094 \times(\mathrm{DAS}-125)$ & 0.221 & 7.58 & 0.0204 \\
\hline & Husk & Before & $101.853-2.510 \times(\mathrm{DAS}-84)$ & 0.848 & 23.85 & $<0.0001$ \\
\hline & & After & $20.791-0.109 \times(\mathrm{DAS}-125)$ & 0.186 & 12.69 & 0.0352 \\
\hline & Stover $^{[\mathrm{c}]}$ & Before & $903.128-17.010 \times(\mathrm{DAS}-84)$ & 0.951 & 8.20 & $<0.0001$ \\
\hline & & After & $206.718-2.754 \times(\mathrm{DAS}-125)$ & 0.656 & 13.08 & $<0.0001$ \\
\hline & Stalk dry matter & Before & $101.331-0.948 \times(\mathrm{DAS}-84)$ & 0.655 & 10.25 & $<0.0001$ \\
\hline & & After & $57.447+0.044 \times(\mathrm{DAS}-125)$ & 0.016 & 6.31 & 0.5521 \\
\hline & Stover to ear ratio ${ }^{[\mathrm{d}]}$ & Before & $2.701-0.052 \times(\mathrm{DAS}-84)$ & 0.954 & 8.27 & $<0.0001$ \\
\hline & & After & $0.731-0.008 \times(\mathrm{DAS}-125)$ & 0.611 & 11.49 & $<0.0001$ \\
\hline \multirow{8}{*}{$\begin{array}{l}\text { Moisture } \\
\text { content } \\
\text { (\% w.b.) }\end{array}$} & Stalk & Before & $84.640-0.463 \times(\mathrm{DAS}-84)$ & 0.543 & 6.96 & $<0.0001$ \\
\hline & & After & $48.582-1.312 \times(\mathrm{DAS}-125)$ & 0.832 & 22.81 & $<0.0001$ \\
\hline & Leaf & Before & $86.396-1.782 \times(\mathrm{DAS}-84)$ & 0.800 & 20.76 & $<0.0001$ \\
\hline & & After & $11.678-0.096 \times(\mathrm{DAS}-125)$ & 0.277 & 16.27 & 0.0083 \\
\hline & Husk & Before & $80.430-2.033 \times(\mathrm{DAS}-84)$ & 0.922 & 17.10 & $<0.0001$ \\
\hline & & After & $12.957-0.155 \times(\mathrm{DAS}-125)$ & 0.262 & 26.50 & 0.0106 \\
\hline & Grain & Before & $55.758-0.867 \times(\mathrm{DAS}-84)$ & 0.982 & 3.71 & $<0.0001$ \\
\hline & & After & $21.976-0.276 \times(\mathrm{DAS}-125)$ & 0.948 & 3.95 & $<0.0001$ \\
\hline
\end{tabular}

[a] "Before" covers 84 to 122 DAS (days after sowing) and "After" covers 125 to 157 DAS.

[b] Mean values of the six plant samples per sampling day were used as the input data.

[c] Stover mass $=$ whole plant mass - whole ear + husk.

[d] Wet mass ratio of stover and dehusked ear. 


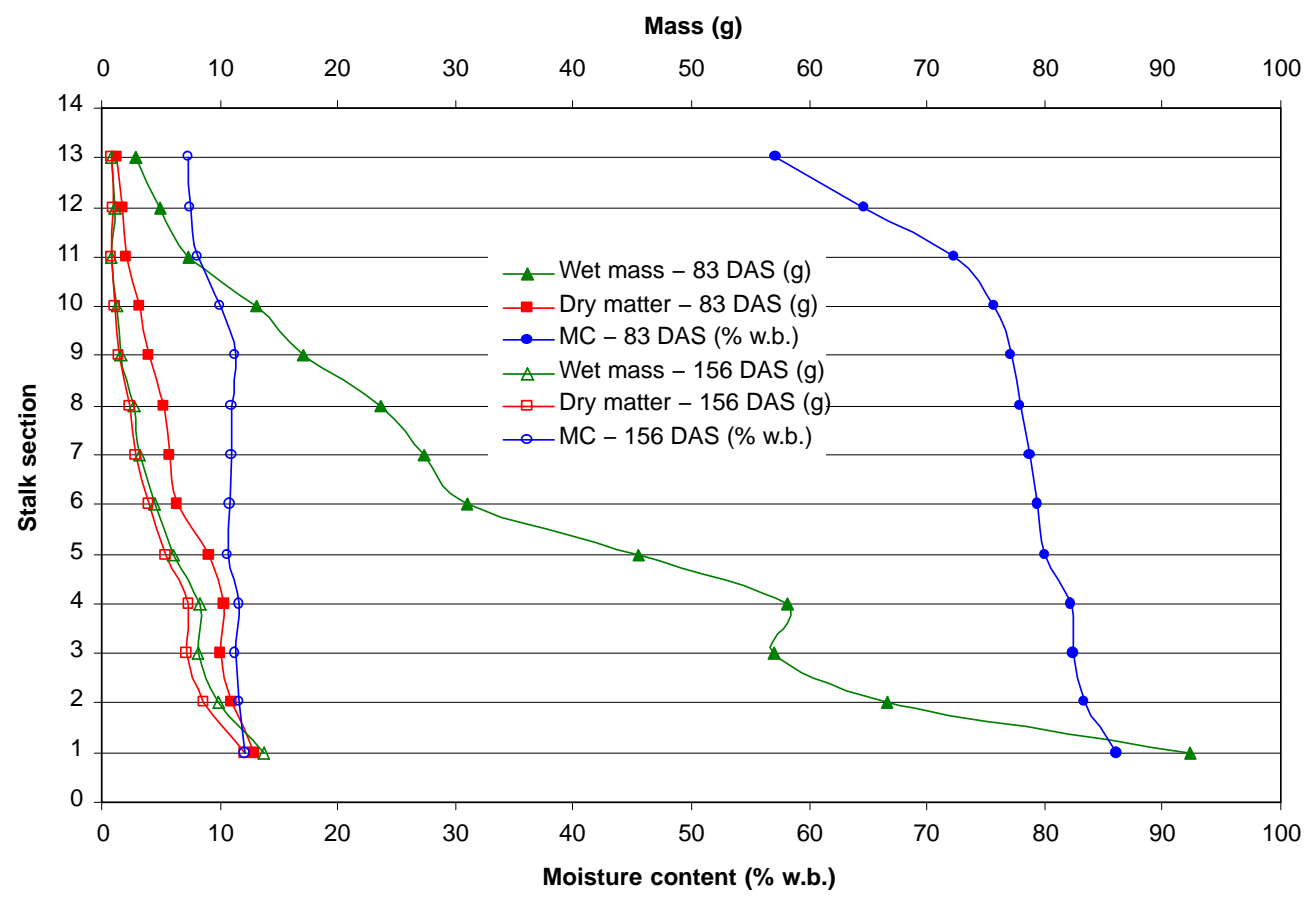

Figure 4. Typical mass and moisture distribution on a single corn stalk sections during two days (83 and 156 DAS).

Table 3. Diameter and volume ratios variation of corn stalk section at two time periods.

\begin{tabular}{|c|c|c|c|c|c|}
\hline \multirow[b]{2}{*}{ Section } & \multirow{2}{*}{$\begin{array}{c}\text { Non- } \\
\text { Dimensional } \\
\text { Height }\end{array}$} & \multicolumn{2}{|c|}{ Diameter Ratio $^{[\mathrm{a}]}$} & \multicolumn{2}{|c|}{ Volume Ratio $^{[\mathrm{b}]}$} \\
\hline & & $\begin{array}{c}98-101 \\
\text { DAS }\end{array}$ & $\begin{array}{c}153-157 \\
\text { DAS }\end{array}$ & $\begin{array}{c}98-101 \\
\text { DAS }\end{array}$ & $\begin{array}{c}153-157 \\
\text { DAS }\end{array}$ \\
\hline 1 & 0.08 & 0.97 & 0.90 & 0.97 & 0.85 \\
\hline 2 & 0.17 & 0.92 & 0.83 & 0.88 & 0.75 \\
\hline 3 & 0.25 & 0.88 & 0.80 & 0.82 & 0.71 \\
\hline 4 & 0.33 & 0.83 & 0.74 & 0.75 & 0.63 \\
\hline 5 & 0.42 & 0.71 & 0.64 & 0.59 & 0.50 \\
\hline 6 & 0.50 & 0.61 & 0.49 & 0.45 & 0.33 \\
\hline 7 & 0.58 & 0.52 & 0.37 & 0.36 & 0.22 \\
\hline 8 & 0.67 & 0.42 & 0.26 & 0.27 & 0.14 \\
\hline 9 & 0.75 & 0.30 & 0.17 & 0.17 & 0.08 \\
\hline 10 & 0.83 & 0.21 & 0.08 & 0.11 & 0.03 \\
\hline 11 & 0.92 & 0.10 & 0.03 & 0.05 & 0.01 \\
\hline 12 & 1.00 & 0.02 & 0.01 & 0.01 & 0.00 \\
\hline
\end{tabular}

[a] Diameter maximum $(25.81 \mathrm{~mm})$ and minimum $(5.50 \mathrm{~mm})$ values were used in normalization.

[b] Volume maximum $\left(132305.04 \mathrm{~mm}^{3}\right)$ and minimum $\left(6043.84 \mathrm{~mm}^{3}\right)$ values were used in normalization.

sectional areas for application of shear failure stress to predict size reduction energy (Womac et al., 2005).

Increase in the ratio of lateral surface area to volume with increasing plant height is shown in figure 5. It is interesting to note that the first five sections had the lowest surface area to volume ratios, with little variation among them, whereas diameter and volume ratios decreased (table 3). Low ratios of lateral surface area to volume imply less exposed area for moisture removal and greater moisture holding capacity, all of which could explain why the larger stalk sections at the bottom remained wetter longer than the smaller diameter stalk sections. An increase in ratio values from the 6th to the 12th sections predicted a progressive increase of moisture transfer potential in the upward direction, and the top sections would dry first in natural field drying. This may explain what would otherwise appear as a drying front moving down the corn stalk. Stalk shrinkage nearly stopped and stalk sections reached dimensional stability from 118 to 157 DAS, as indicated by the grouped curves (fig. 5).

\section{Vertical Distribution of Dry Matter and Moisture Content in Stalk Sections}

Vertical distribution of dry matter ratios in stalk sections based on weekly average data is plotted in figure 6 . The normal harvest period separated the dry matter ratio vertical distribution curves into two distinct groups. The grouping of curves after 120 DAS indicated negligible dry matter loss. Therefore, a delay soon after harvest should not affect available dry matter for intact stalks. It should be noted that significant mechanical disturbance by a harvester may reverse this observation. On average, based on weekly combined data, dry matter contribution by the bottom 1 to 4 and 1 to 3 stalk sections was $60.57 \% \pm 3.49 \%$ and $48.41 \%$ $\pm 3.33 \%$, respectively, indicating the importance of reduced harvester header height to maximize stover recovery. Cuts close to the ground also harvest more "moisture," which may require additional drying effort for some applications or may be advantageous for some wet procedures. Johnson and Lamp (1966) reported that cutting corn plants at the soil surface added $10 \%$ more stover yield over normal harvesting practices. But cuts too close to the ground level may increase soil contamination of biomass and require additional cleaning. Shinners et al. (2003) observed that roughly $50 \%$ of total stover dry matter was present at the bottom $1 / 4$ of the stalk.

The location of representative "average" dry matter, for future stalk sampling schemes, was found to be the 7th and 6th stalk sections for before-harvest and after-harvest, respectively, when 14 sections were considered. With 12 stalk sections, the 6th section represented the average dry matter throughout the experimental period. This information may be useful for biomass yield estimation.

Vertical distribution of stalk moisture content based on weekly average is shown in figure 7 . Moisture loss occurred 


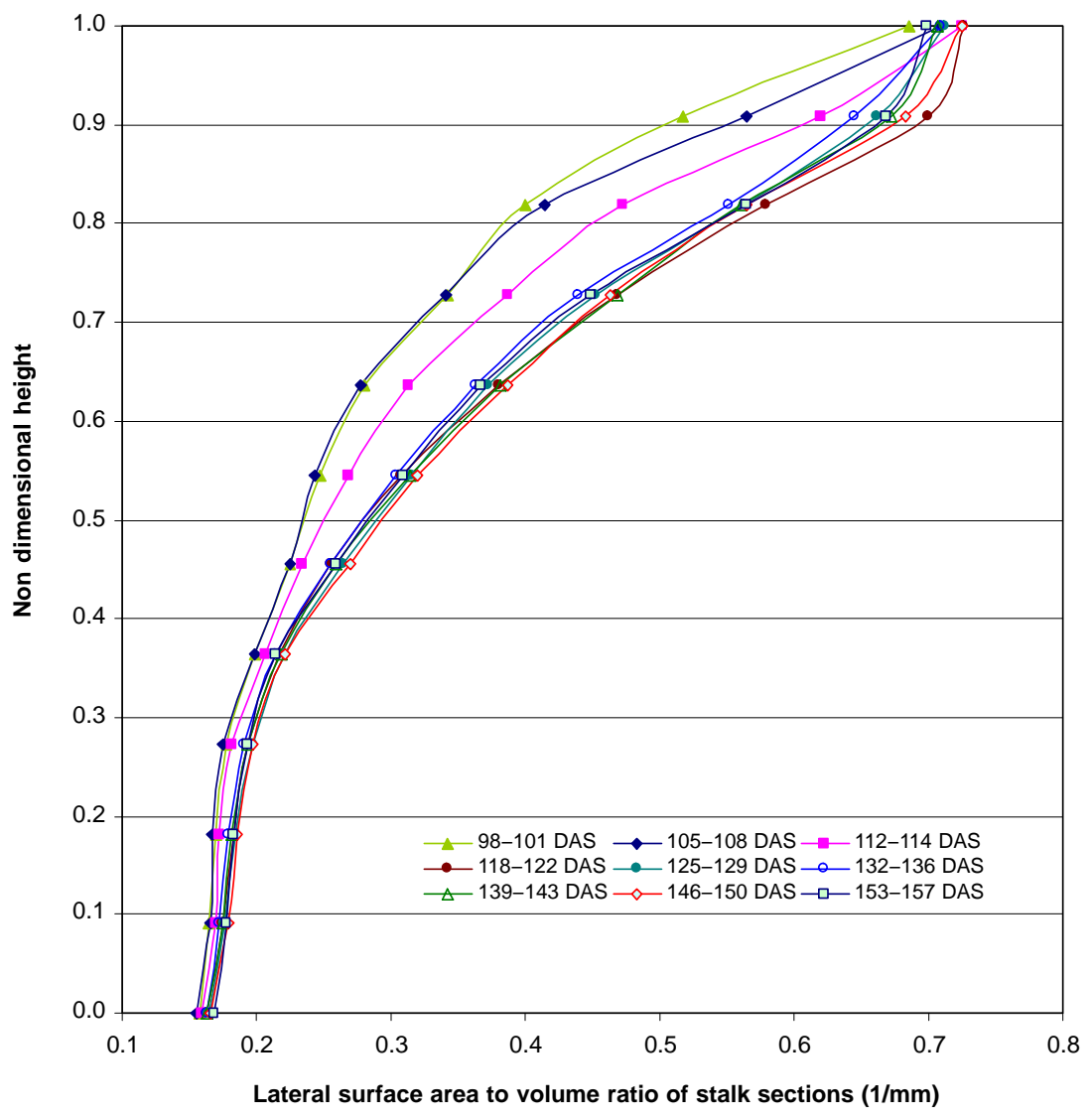

Figure 5. Lateral surface area to volume ratios along the vertical direction of corn stalk sections.

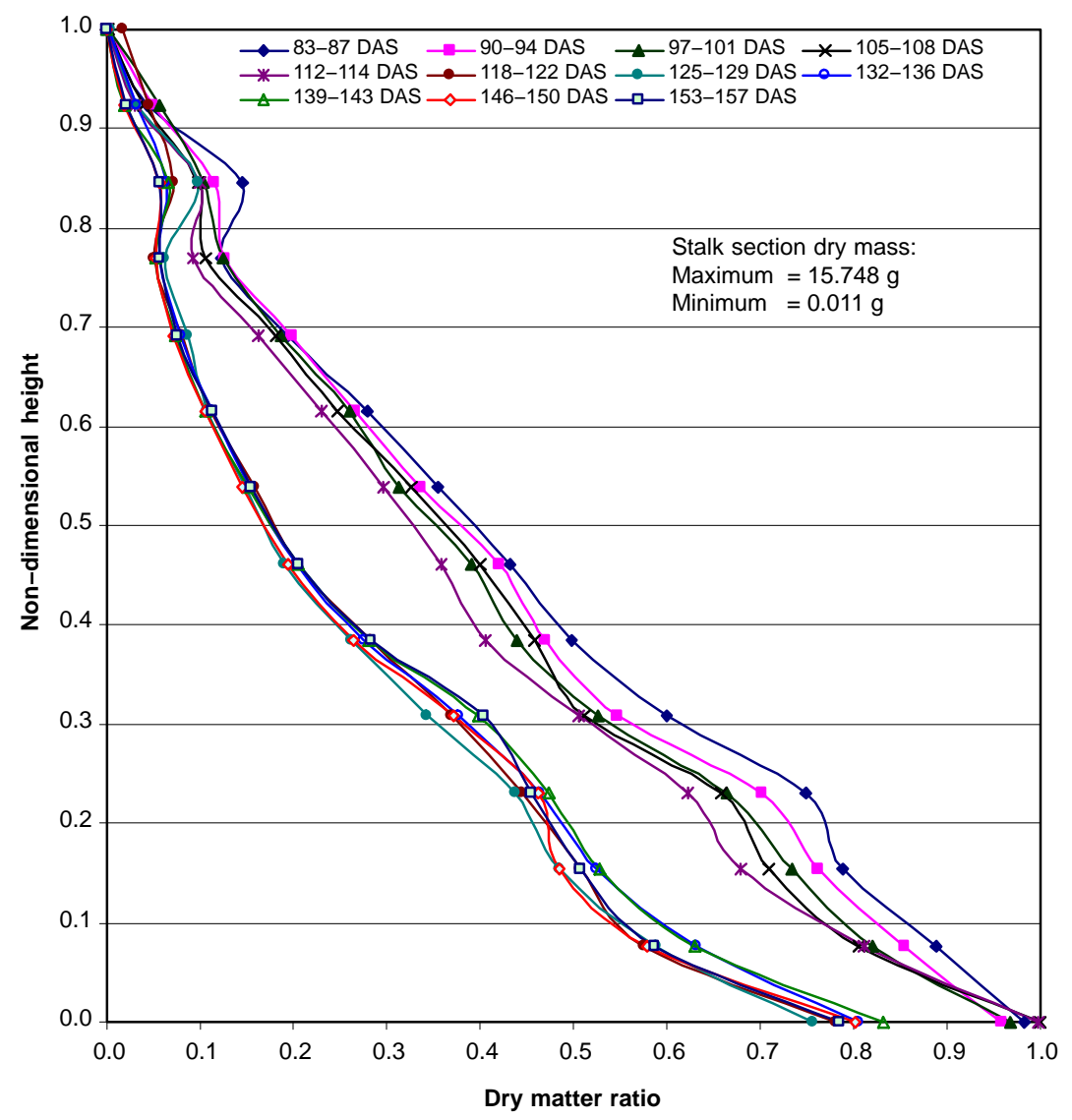

Figure 6. Vertical distribution of weekly average dry matter ratios of corn stalk sections. 


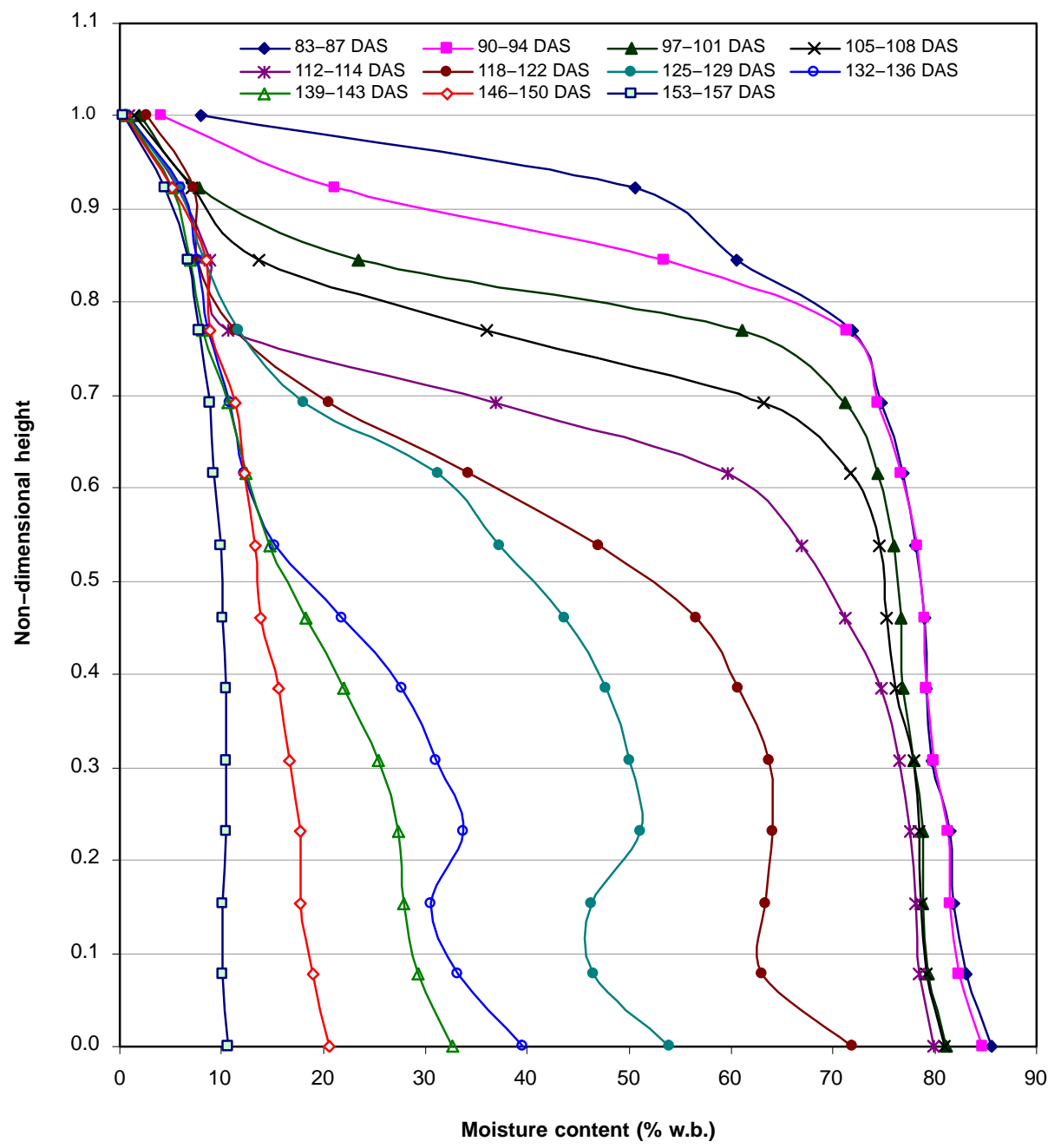

Figure 7. Vertical distribution of weekly average moisture content of corn stalk sections.

at a slower rate at the bottom sections than at the top sections, as predicted by the ratios of stalk surface area to volume (fig. 5). The top stalk sections (>10th) reached a stable moisture content of $<11.3 \%$ by the normal harvest period, but mean moisture content of the 1 st to 4 th sections was $\sim 65.5 \%$ during the same time. Stalk sections below the 11th lost moisture rapidly after 114 DAS. The middle sections (3rd to 7th) dried collectively, with more moisture reduction around the normal harvest period. No noticeable breakdown in stalk integrity was observed during rapid moisture reduction. A nearly constant moisture profile of $10.4 \%$ was observed up the stalk during the final period (153 to 157 DAS). Polynomial mass and moisture relationships of individual stalk sections, in terms of DAS, and mass and moisture variations of above and below ear stalk segments were previously reported (Igathinathane et al., 2004). Since the rainfalls received did not have a noticeable effect on stalk moisture contents $(r=$ $0.004, p=0.8193$ ), it is hypothesized that the moisture quickly drained off the stalk skin of standing stalks with little opportunity for internal moisture penetration throughout the experimental period.

\section{CORRelation ANALYSIS}

Correlation analyses between stalk dry matter, moisture content, experiment factors, and environmental factors are shown in table 4 . Stalk section dry matter was well correlated
Table 4. Correlation analysis on the selected parameters.

\begin{tabular}{|c|c|c|c|c|}
\hline \multirow[b]{3}{*}{ Variable } & \multicolumn{4}{|c|}{$\begin{array}{l}\text { Pearson Correlation Coefficients } \\
(r) \text { and } p \text { Values }\end{array}$} \\
\hline & \multicolumn{2}{|c|}{$\begin{array}{l}\text { Dry Matter } \\
(\mathrm{g})\end{array}$} & \multicolumn{2}{|c|}{$\begin{array}{l}\text { Moisture Content } \\
\text { (\% w.b.) }\end{array}$} \\
\hline & $r$ & $p$ & $r$ & $p$ \\
\hline$\overline{\mathrm{DAS}}$ & -0.256 & $<0.0001$ & -0.802 & $<0.0001$ \\
\hline Replication & 0.030 & 0.0812 & 0.060 & 0.0004 \\
\hline Sample & -0.025 & 0.1342 & -0.092 & $<0.0001$ \\
\hline Stalk section & -0.887 & $<0.0001$ & -0.342 & $<0.0001$ \\
\hline Wet mass (g) & 0.840 & $<0.0001$ & 0.719 & $<0.0001$ \\
\hline Dry matter $(\mathrm{g})$ & 1.000 & -- & 0.512 & $<0.0001$ \\
\hline Moisture content ( $\%$ w.b.) & 0.512 & $<0.0001$ & 1.000 & -- \\
\hline Soil moisture (\% w.b.) & -0.148 & $<0.0001$ & -0.298 & $<0.0001$ \\
\hline Soil temperature $\left({ }^{\circ} \mathrm{C}\right)$ & 0.192 & $<0.0001$ & 0.612 & $<0.0001$ \\
\hline Solar radiation $\left(\mathrm{MJ} /\left(\mathrm{m}^{2} \cdot \mathrm{s}\right)\right)$ & 0.113 & $<0.0001$ & 0.344 & $<0.0001$ \\
\hline Rainfall (mm/day) & -0.033 & 0.0493 & 0.004 & 0.8193 \\
\hline Air temperature $\left({ }^{\circ} \mathrm{C}\right)$ & 0.231 & $<0.0001$ & 0.722 & $<0.0001$ \\
\hline Air relative humidity (\%) & 0.039 & 0.0206 & 0.184 & $<0.0001$ \\
\hline Wind direction $\left({ }^{\circ} \mathrm{N}\right)$ & 0.018 & 0.2823 & 0.060 & 0.0004 \\
\hline Wing speed $(\mathrm{m} / \mathrm{s})$ & -0.091 & $<0.0001$ & -0.201 & $<0.0001$ \\
\hline$E T_{\mathrm{o}} \mathrm{FAO} 56-\mathrm{PM}(\mathrm{mm} /$ day $)$ & 0.209 & $<0.0001$ & 0.630 & $<0.0001$ \\
\hline
\end{tabular}

with stalk section number $(r=-0.89)$ and wet mass $(r=0.84)$, but was less correlated with moisture content $(r=0.51)$. Soil and environmental factors had reduced correlation with dry 
Table 5. Overall mass and moisture multiple regression relationships of stalk sections. [a]

\begin{tabular}{|c|c|c|c|}
\hline Equation $^{[b]}$ & $\mathrm{R}^{2}$ & $\mathrm{CV}(\%)$ & $\operatorname{Pr}>\mathrm{F}$ \\
\hline Wet mass ratio ${ }^{[\mathrm{c}]}=1.684-0.010 \times \mathrm{DAS}-2.088 \times S+0.357 \times S^{2}+0.011 \times \mathrm{DAS} \times S$ & 0.930 & 31.62 & $<0.0001$ \\
\hline Dry matter ratio $^{[\mathrm{d}]}=1.317-0.005 \times \mathrm{DAS}-1.633 \times S+0.539 \times S^{2}+0.003 \times \mathrm{DAS} \times S$ & 0.954 & 17.36 & $<0.0001$ \\
\hline Moisture content $(\%$ w.b. $)=199.165-1.206 \times \mathrm{DAS}-8.013 \times S-48.534 \times S^{2}+0.201 \times \mathrm{DAS} \times S$ & 0.875 & 22.95 & $<0.0001$ \\
\hline
\end{tabular}

[a] Based on Dekalb 743 corn planted on May 2003; hence, estimations may vary with other varieties, crops, and growing conditions.

[b] Days after sowing (DAS) varies from 83 to 157 , and non-dimensional height $(S)$ varies from 0.0 to 1.0 , normalized using 12 sections.

[c] Normalized using minimum and maximum wet mass values of data as (wet mass of section $-0.740 \mathrm{~g}) /(121.177 \mathrm{~g}-0.740 \mathrm{~g}$ ).

[d] Normalized using minimum and maximum dry matter values of data as (dry matter of section $-0.698 \mathrm{~g}) /(17.327 \mathrm{~g}-0.698 \mathrm{~g})$.

matter $(|r|=0.02$ to 0.23$)$, but had relatively increased correlation values with moisture content $(|r|=0.004$ to 0.72 ). Among soil and environmental factors, air temperature, reference evapotranspiration, and soil temperature produced better correlations with dry matter and moisture content. Rainfall was less correlated $(|r|<0.03)$ with dry matter and moisture content of stalk sections. Dry matter was highly correlated with stalk section $(r=-0.89)$ and wet mass $(r=0.84)$. Less correlation between dry matter and DAS $(r=-0.26)$ was due to the observed stable dry matter after physiological maturity. In the case of moisture content, independent variables DAS, wet mass, soil temperature, air temperature, and evapotranspiration had good correlation $(|r|>0.61)$.

\section{Fitting of Mass and Moisture Relationship for Stalk Sections}

Overall equations for wet mass ratio, dry matter ratio, and moisture content of stalk sections in terms of non-dimensional heights and DAS using multiple regressions are presented in table 5. Equations were developed using non-dimensional heights to facilitate other crops, although caution should be exercised, especially for crops with geometrical stalk/plant dimensions much different from corn. Regressions included non-dimensional height $(S)$ plus an additional higher-order term $\left(S^{2}\right)$ and one interaction with non-dimensional height $(\mathrm{DAS} \times S)$. Additional variables $\left(S^{2}\right.$ and $\left.\mathrm{DAS} \times S\right)$ were statistically significant $(p<0.0007)$.

\section{Conclusions}

Moisture profile in standing corn stover exhibited two separate, sequential linear relationships when plotted with time. The first zone was rapid moisture reduction prior to the normal harvest period. The second zone, corresponding with but not the result of grain harvest, had slow, gradual moisture reduction and stabilization. Collection of the entire stalk of standing stover with the least moisture would be best accomplished no sooner than about one month after normal grain harvest.

Moisture status along the corn stalk was related to the ratio of lateral surface area to volume, with increased stalk diameter correlating with increased moisture. Stover collection management should consider whether the increased moisture in the plant base should be avoided by raising the height of collection. Decisions to avoid the increased moisture should examine biomass end use and conversion sensitivity to moisture, spoilage potential, drying costs, and transportation costs.

Soil and environmental parameters, including rainfall, had negligible effect on dry matter (mean $|r|=0.12$ ) and moisture content (mean $|r|=0.34$ ) of standing stalks in the field. It was hypothesized that moisture quickly drained off the stalk skin of standing stalks with little opportunity for moisture penetration. Collection of undisturbed standing stalks may be less prone to degradation than disturbed and shattered corn stover.

\section{ACKNOWLEDGEMENTS}

The authors appreciate the financial support by the Bioenergy Feedstock Development Program of the Oak Ridge National Laboratory (Subcontract No. 34000008088). Assistance extended by Bobby R. McKee, Senior Farm Crew Leader, and his crew members at The University of Tennessee Knoxville Experiment Station is highly appreciated. Thanks are extended to Wesley C. Wright for his help with weather data acquisition and evapotranspiration analysis, and Hong Y. Jeon, Michael R. Williams, Gnanambiga L. Sahiram, and Manlu Yu for their help with field sample collection and measurements.

\section{REFERENCES}

Aldrich, S. R., and E. R. Leng. 1966. Section 1: How the corn plant grows. In Modern Corn Production, 1-15. 2nd ed. Cincinnati, Ohio: F\&W Publishing.

Allen, R. G. 2000. REF-ET Reference Evapotranspiration Calculation Software for FAO and ASAE Standardized Equations. Ver. 2.0. Moscow, Idaho: University of Idaho.

ASAE Standards. 2003. S358.2: Moisture measurement - forages. St. Joseph, Mich.: ASAE.

Cummins, D. G. 1970. Quality and yield of corn plants and component parts when harvested for silage at different maturity stages. Agron. J. 62(2): 781-784.

Edens, W. C., L. O. Pordesimo, and S. Sokhansanj. 2002. Field drying characteristics and mass relationships of corn stover fractions. ASAE Paper No. 026015. St. Joseph, Mich.: ASAE.

Glassner, D., J. Hettenhaus, and T. Schechinger. 1999. Corn stover potential: Recasting the corn sweetener industry. In Perspectives on New Crops and New Uses, 74-82. J. Janick, ed. Alexandria, Va.: ASHS Press.

Hettenhaus, J. R., and R. Wooley. 2000. Biomass commercialization prospects in the next two to five years.

NREL/ACO-9-29-039-01. Golden, Colo.: National Renewable Energy Laboratory.

Igathinathane, C., A. R. Womac, S. Sokhansanj, and L. O. Pordesimo. 2004. Vertical mass and moisture distribution in standing corn stalks. ASAE Paper No. 041162. St. Joseph, Mich.: ASAE.

Iowa State University. 1993. Corn stover - a low cost alternative for flood-shortened feed supplies. Ames, Iowa: Iowa State University Extension.

Jara, J., C. O. Stockle, and J. Kjelgaard. 1998. Measurement of evapotranspiration and its components in corn (Zea mays L.) field. Agric. and Forest Meteorology 92(2): 131-145.

Jenkins, B. M., and H. R. Sumner. 1986. Harvesting and handling agricultural residues for energy. Trans. ASAE 29(3): 824-836. 
Johnson, W. H., and B. J. Lamp. 1966. Principles, Equipment, and Systems of Corn Harvesting. Wooster, Ohio: Agricultural Consulting Associates, Inc.

Kadam, K. L., and J. D. McMillan. 2003. Availability of corn stover as a sustainable feedstock for bioethanol production. Bioresource Tech. 88(1): 17-25.

Leask, W. C., and T. B. Daynard. 1973. Dry matter yield, in vitro digestibility, percent protein, and moisture of corn stover following grain maturity. Canadian J. Plant Sci. 53(3): 515-522.

Pordesimo, L. O., W. C. Edens, and S. Sokhansanj. 2004. Distribution of aboveground biomass in corn stover. Biomass and Bioenergy 26(4): 337-343.

Russell, J. R. 1986. Influence of harvest date on the nutritive value and ensiling characteristics of maize stover. Animal Feed Sci. Tech. 14(1-2): 11-27.

SAS. 2002. SAS 9 Online help and documentation. Cary, N.C.: SAS Institute, Inc.

Shinners, K. J., B. N. Binversie, and P. Savoie. 2003. Harvest and storage of wet and dry corn stover as a biomass feedstock. ASAE Paper No. 036088. St. Joseph, Mich.: ASAE.
Sokhansanj, S. 2005. Feedstock supply logistics: DOE/USDA Biomass Feedstock Gate Review Meeting, March 14-16, 2005. Oak Ridge, Tenn.: Oak Ridge National Laboratory. Available at: http://feedstockreview.ornl.gov/pdf/sokhansanj/session2_sokhan sanj.pdf. Accessed 18 August 2005.

Sokhansanj, S., and L. Wright. 2002. Impact of future biorefineries on feedstock supply systems, equipment, and infrastructure. ASAE Paper No. 021073. St. Joseph, Mich.: ASAE.

Sokhansanj, S., A. Turhollow, J. Cushman, and J. Cundiff. 2002. Engineering aspects of collecting corn stover for bioenergy. Biomass and Bioenergy 23(5): 347-355.

USDA. 2005. Production supply and distribution official statistics. Washington, D.C.: USDA Foreign Agricultural Service. Available at:

www.fas.usda.gov/psd/complete_files/GF-0440000.csv Accessed 10 June 2005.

Weisstein, E. W. 2005. Conical frustum. In MathWorld. Champaign, Ill.: Wolfram Research, Inc. Available at: http://mathworld.wolfram.com/ConicalFrustum.html. Accessed 29 July 2005.

Womac, A. R., M. Yu, C. Igathinathane, X. Ye, D. Hayes, S. Narayan, S. Sokhansanj, and L. Wright. 2005. Shearing characteristics of biomass for size reduction. ASAE Paper No. 056058. St. Joseph, Mich.: ASAE. 